\title{
Histological study of the developing gonads of endangered freshwater spiny eel, Mastacembelus armatus during the reproductive cycle
}

\author{
M. R. Ali, M. M. Rahman, M. R. I. Sarder and M. F. A. Mollah \\ Department of Fisheries Biology and Genetics, Bangladesh Agricultural University Mymensingh-2202, Bangladesh, \\ *E-mail: rahman.matiur@bau.edu.bd
}

\begin{abstract}
The spiny eel, Mastacembelus armatus is one of the most common and economically important inland teleost species of Asia having high market and nutritive values. The demand for the fish is almost always exceeds its supply. Histological analysis of developmental stages of both oocytes and sperrnatocytes maturation were undertaken and dimensions of ovarian oocytes were observed to evaluate the annual reproductive condition of $M$. armatus during August 2012 to July 2013. Monthly sampling of adult individuals of M. armatus was done from haor region of Kishoreganj district, Bangladesh. Both the gonads were paired, elongated and of unequal in length. The colour of ovaries varied from reddish brown to light yellowish; whereas, testes varied from whitish to creamy or dull white. From the histological study, five stages of oocyte development (oogonia, chromatin nucleolar stage oocyte, perinucleolar stage oocytes, yolk vesicle oocyte, and yolk granule stage) were observed upon their changes in nucleus. Female $M$. armatus having immature stages of oocytes (early and late perinucleolar stage oocytes) were mostly available in the months of November and December. Yolk vesicle stage oocytes appeared during the months of January and February. Early yolk granule stage oocytes appeared during the months of March and April while late yolk granule stage oocytes were observed during the months of May and June. Oocytes and nuclei diameters were observed ranged from 12-1050 $\mu \mathrm{m}$ and 10-212 $\mu \mathrm{m}$, respectively until ovulation. In male gonads, four stages of spermatogenesis (spermatogonia, spermatocytes, spermatids, and spermatozoa) were distinguished during the study period where spermatids were prominent in January to March and spermatozoa in April to July. From this study, the peak gonadal development of $M$. armatus is found in June and thus, it is clearly indicated that the fish breed during May to June.
\end{abstract}

Keywords: Mastacembelus armatus, Histology, Gonad

\section{Introduction}

The Spiny Eel, Mastacembelus armatus is a common fish species of Indian sub-continent that belongs to the family Mastacembelidae under the order Synbranchiformes. It is native to the fresh and brackish waters in Bangladesh, Pakistan, Sri Lanka, Myanmar, Nepal, Thailand, Cambodia, Vietnam, Northeastern India and other parts of South East Asia (Talwar and Jhingran, 1991). M. armatus is one of the most popular table fishes with delicious flesh quality having a special flavor, characteristic texture and high protein, oil and vitamin $\mathrm{C}$ content. Its market value is double than that of carp species in Bangladesh (Rahman et al., 2006; Ali et al., 2013). Although the estimated area of occupancy and extent of occurrence of $M$. armatus indicate its wide distribution throughout its range, the reduction of its population was easily speculated based on local accounts collected through field visits and personal communication with local people. It is assumed that this species has reduced more than $50 \%$ by the last two decades and thus categorized as endangered species (Ahmed, 2015; IUCN, 2015). This species, therefore, needs protection from being extinct through the development of its breeding and culture technique. To evaluate the reproductive potentials of $M$. armatus, information on the fecundity, reproductive biology, behaviour and breeding season are considered essential (Rahman et al., 2004). There are few reports only on food and feeding habit, rearing technique under laboratory condition, morphometric and meristic measurements, and some aspects of reproductive biology of $M$. armatus so far available (Serajuddin et al., 1998; Narejo et al., 2003; Rahman et al., 2004; Serajuddin and Pathak, 2012; Alam et al., 2013; Patwary, 2013; Mollah et al., 2013; Gupta and Banerjee, 2016). However, basic information on the cyclic changes of the reproductive glands that are important to onset successful breeding strategy of $M$. armatus is indispensable. 
One of the most important studies of fishery biology is to determine the annual breeding cycle of a fish species. There are a few methods, such as gonad indexes, staging based on the external appearance of the gonad and measurements of gonad size and histology to assess the stage of gonad development of individual fish. Despite expensive and time-consuming procedures being used to determine gonad development, the most accurate technique is histological analysis (West, 1990). The spawning period in teleosts is determined from changes occurring within the gonad throughout the year. The macroscopic or histological observations of the gonad (qualitative method) and evaluation of oocyte diameter (quantitative method) are commonly applied (Karlou-Riga and Economidis, 1997). This technique also helps in detecting the breeding season and establishing phenotypic characters of fully mature breeders for successful induced breeding of the concerned species. So, it is essential to conduct histological study of gonad to ascertain cycle of breeding season of $M$. armatus. A very little data is available on gonadal histology and reproductive biology of $M$. armatus. Therefore, the present study was conducted to examine maturation and histological changes of the gonads of $M$. armatus over an annual reproductive cycle.

\section{Materials and Methods}

\section{Collection of fish samples}

Live M. armatus were collected from haor region of Kishoreganj district, Bangladesh at the middle of each month during August 2012 to July 2013. Collections were made to cover a year-long study so that a clear picture of the seasonal changes in the gonads could be demonstrated. The fish were carried in oxygenated plastic bag containing water. In this study, $M$. armatus were anaesthetized with $0.02 \%$ clove oil (Keene et al., 1998). Individual M. armatus was then measured for total length to the nearest $\mathrm{cm}$ and body weight to the nearest $\mathrm{g}$. At least 10 specimens from each sex were sacrificed in every month. Gonad was dissected out from the body cavity and then small pieces (about 1-2 cm) from the gonads were fixed at Bouin's solution (gonad and solution ratio 1:10) for subsequent studies.

\section{Measurement of ova diameter}

After dissecting out of the ovary of a female $M$. armatus, a small representative part from anterior, posterior, and middle portion of the same was taken separately. The ova of the samples were separated keeping in a physiological saline solution $(0.85 \% \mathrm{NaCl})$ and spread on a glass slide to measure the diameter of ova under the microscope using magnification of 10x (eye piece) and $4 \times, 10 \times, 20 x, \& 40 \times$ (objective) with the help of an ocular micrometer (100 division). However, at least 100 ova of a single sample were measured and observed values for ova diameter were expressed in $\mathrm{mm}$.

\section{Histological study of gonads}

The small pieces of preserved gonads, measuring about 4-5 $\mathrm{mm}$ in length were taken out in a perforated plastic holder, which was covered by perforated steel plate. Dehydration, clearing and infiltration were carried out in an automatic tissue processor (Tissue-Tek Rotary, Model-RX-IIB, Made in Japan) using a series of alcohol of increasing concentrations, three changes of xylene and finally through molten paraffin wax (two series). The samples were then embedded in melted paraffin wax. Yolk-laden tissues were, however, very brittle and difficult to section when embedded routinely. This drawback was due to the difficulty in getting the wax penetrated into the yolky region of the oocytes. It was found that yolky oocytes required a very specific timing for dehydration and wax infiltration. Paraffin wax embedded tissue blocks were sectioned by microtome knife at 4-5 $\mu \mathrm{m}$ thickness and the sections were kept into a water bath at a temperature of $40^{\circ} \mathrm{C}$ for stretching so that they can be placed on glass slide easily. Slides were then kept overnight on a slide drier at a temperature of $40^{\circ} \mathrm{C}$. The sections were attached to slide using Mayer's egg albumin. A small drop of Mayer's egg albumin was smeared over the surface of the slide with the finger and the excess amount was rubbed off. Then the sections were stained routinely with hematoxylin and eosin according to Humason (1972). 


\section{Microscopic examination of the gonadal tissue}

The stained sections were mounted on the glass slide with DPX mountant and covered by cover slips and studied under a compound microscope (Olympus, Model-BX-51, USA). The photographs were also taken simultaneously for future documents of the study.

\section{Results}

\section{Secondary sexual characters}

Sexually mature male and female $M$. armatus could be distinguished on the basis of the appearance of the genital papillae. The male genital papilla appeared long and protruded, while that of female was oval in shape.

\section{The morphology of the ovaries and testes}

Ovaries, the female reproductive organ were paired, elongated with various widths frilled ribbon like structure lying ventral to the body cavity and were of unequal length, with the right ovary commencing further forward than the left ovary, anterior to the gall bladder (Fig. 1A). The left ovary extended posteriorly beyond the right ovary. The two lobes were connected along the dorsal surface by mesenteries, from which they were suspended in the posterior ends into a short oviduct, which fused and led to the urino-genital pore. The colour of ovary varied from reddish brown to light yellowish.

The male reproductive system of $M$. armatus consisted of a pair of testes that were elongated, situated on either side, ventral to the kidneys in the posterior region of the abdominal cavity and attached to the dorsal body wall by the connective tissue, the mesorchium. Testes were extended unequally along both sides. The colour of testes varied from whitish to creamy white or dull white and were smooth on both sides with distinct lobe (Fig. 1B).
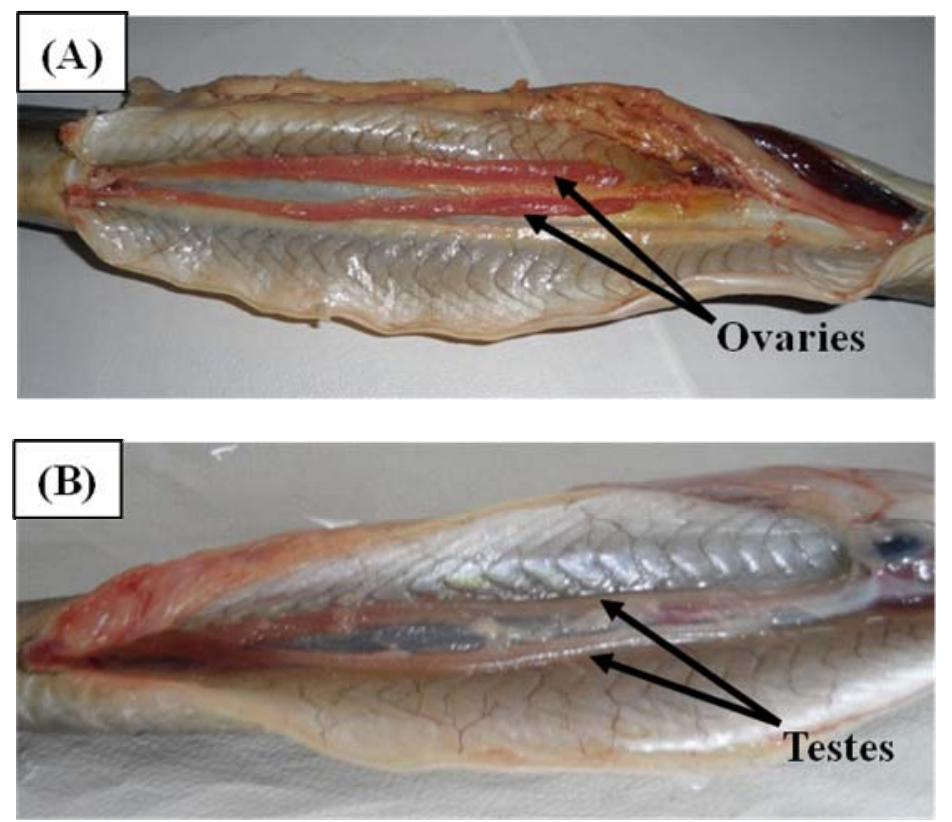

Fig. 1. Location and morphology of ovaries (A) and testes (B) of M. armatus 


\section{The histology of the ovaries}

The wall of the ovary was fairly thick out of breeding season but became thin and highly vascular during the spawning period. In the ovigerous lamellae the germ cells, oogonia were found in bunch in the immature phase of the ovary. The different types of oocytes and their size $(\mu \mathrm{m})$ observed in the prepared slides of $M$. armatus are given in Table 1.

Table 1. Size $(\mu \mathrm{m})$ of different oocytes and nuclei (minimum and maximum values) observed during study period (mean value in parenthesis)

\begin{tabular}{|c|c|c|c|}
\hline Developmental Stage & $\begin{array}{c}\text { No. of } \\
\text { observations }\end{array}$ & $\begin{array}{l}\text { Size of Oocytes } \\
\text { (mean } \pm S D)\end{array}$ & $\begin{array}{l}\text { Size of Nuclei } \\
\text { (mean } \pm S D)\end{array}$ \\
\hline Oogonial stage & 30 & $12-20 \mu \mathrm{m}(15.20 \pm 2.40 \mu \mathrm{m})$ & - \\
\hline Chromatin nucleolar stage & 30 & $15-26 \mu \mathrm{m}(19.03 \pm 3.46 \mu \mathrm{m}))$ & $\begin{array}{c}10-12 \mu \mathrm{m}(10.97 \pm 0.93 \\
\mu \mathrm{m})\end{array}$ \\
\hline Early perinucleolar stage & 30 & $40-75 \mu \mathrm{m}(69.43 \pm 8.62 \mu \mathrm{m})$ & $\begin{array}{c}15-35 \mu \mathrm{m}(27.87 \pm 5.26 \\
\mu \mathrm{m})\end{array}$ \\
\hline Late perinucleolar stage & 30 & $98-260 \mu \mathrm{m}(168 \pm 60.01 \mu \mathrm{m})$ & $\begin{array}{c}48-166 \mu \mathrm{m} \\
(104.80 \pm 39.55 \mu \mathrm{m})\end{array}$ \\
\hline Yolk vesicle stge & 30 & $\begin{array}{c}235-560 \mu \mathrm{m} \\
(345.03 \pm 105.98 \mu \mathrm{m})\end{array}$ & $\begin{array}{c}75-215 \mu \mathrm{m} \\
(126.10 \pm 46.58 \mu \mathrm{m})\end{array}$ \\
\hline Early yolk granule stage & 30 & $\begin{array}{c}560-835 \mu \mathrm{m}(615.13 \pm 90.40 \\
\mu \mathrm{m})\end{array}$ & - \\
\hline Late yolk granule stage & 30 & $\begin{array}{c}755-1050 \mu \mathrm{m} \\
(986.17 \pm 85.20 \mu \mathrm{m})\end{array}$ & - \\
\hline
\end{tabular}

\section{Oogonia and Chromatin nucleolar stage}

Chromatin nucleolar stage oocytes were distinguished from the oogonia by the presence of distinct chromatin threads within the ooplasm. Diameter of oocytes at this stage varied from 15-26 $\mu \mathrm{m}$ (average $19.03 \pm 3.46 \mu \mathrm{m}$ ) with a nuclear diameter of 10-12 $\mu \mathrm{m}$ (average 10.97 $\pm 0.93 \mu \mathrm{m}$ ) (Fig. 2A \& Table 1). This stage was observed during the month of October. In the same sample some of the oogonia (Fig. 2A) were found in single or in small nests. oogonia were shrinking, surrounded by thecal and follicular cells and creating pyknotic cells. Follicle cells and broken parts of oogonia were scattered in the area creating numerous empty spaces during this time. Numerous connective tissues were seen between the oogonia.

\section{Early perinucleolar stage}

Early perinucleolar oocytes, diameter of which ranged from 40-75 $\mu \mathrm{m}$ (average $69.43 \pm 8.62 \mu \mathrm{m}$ ) could be easily identified by the peripheral arrangement of a large number of small nucleoli on the inner side of the nuclear membrane. Their shapes varied, probably depending upon the stress imposed on them by expanding oocytes around them. The diameter of nuclei ranged from 15-35 $\mu \mathrm{m}$ (average 27.87 $\pm 5.26 \mu \mathrm{m}$ ) (Fig. 2B \& Table 1). This stage was observed predominantly during the month of November.

\section{Late perinucleolar stage}

Oocytes at this stage became larger in size, ranging from 98-260 $\mu \mathrm{m}(168 \pm 60.01 \mu \mathrm{m})$ in diameter. The

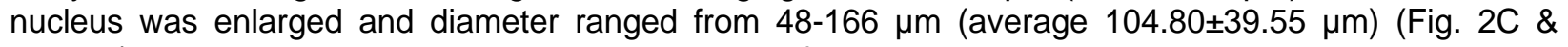
Table 1). This stage was observed during the month of December.

\section{Yolk vesicle stage}

The diameter of oocytes at this stage varied from 235-560 $\mu \mathrm{m}(345.03 \pm 105.98 \mu \mathrm{m})$ with a nuclear diameter of $75-215 \mu \mathrm{m}(126.10 \pm 46.58 \mu \mathrm{m})$. This stage was characterized by the formation of yolk vesicles in the periphery of the ooplasm. Initially they formed as a single row which appeared colourless when the slides were stained with hematoxylin and eosin. These yolk vesicles developed initially as minute bodies but gradually increased in size (diameter: $6.23 \pm 2.07 \mu \mathrm{m}$ ) and number to form several irregular peripheral rows, but in some cases, they also appeared elsewhere in the nucleus (Fig. 2D). This stage was observed during the months of January and February. 


\section{Early yolk granule stage}

The final stage of vitellogenesis and oocyte development was characterized by the formation of yolk granules. Oocytes diameter at this stage were generally between 560 and $835 \mu \mathrm{m}(615.13 \pm 90.40 \mu \mathrm{m})$. Yolk granules formed only in oocytes with fully developed yolk vesicles. The yolk granules first appeared close to the zonaradiata. At a later stage the whole oocyte was filled with yolk granules (Fig. 2E). This stage was observed during the months of March and April.

\section{Late yolk granule stage}

The diameter of the oocytes increased with the advancement of yolk granule stage. The oocyte at this stage might reach a diameter as big as $1050 \mu \mathrm{m}(986.17 \pm 85.20 \mu \mathrm{m})$ while the individual granules were about $30 \mu \mathrm{m}$ or less in diameter. In some cases the yolk granules appeared to coalesce to form larger tightly packed granules (Fig. 2F). This stage was observed during the months of May to June.
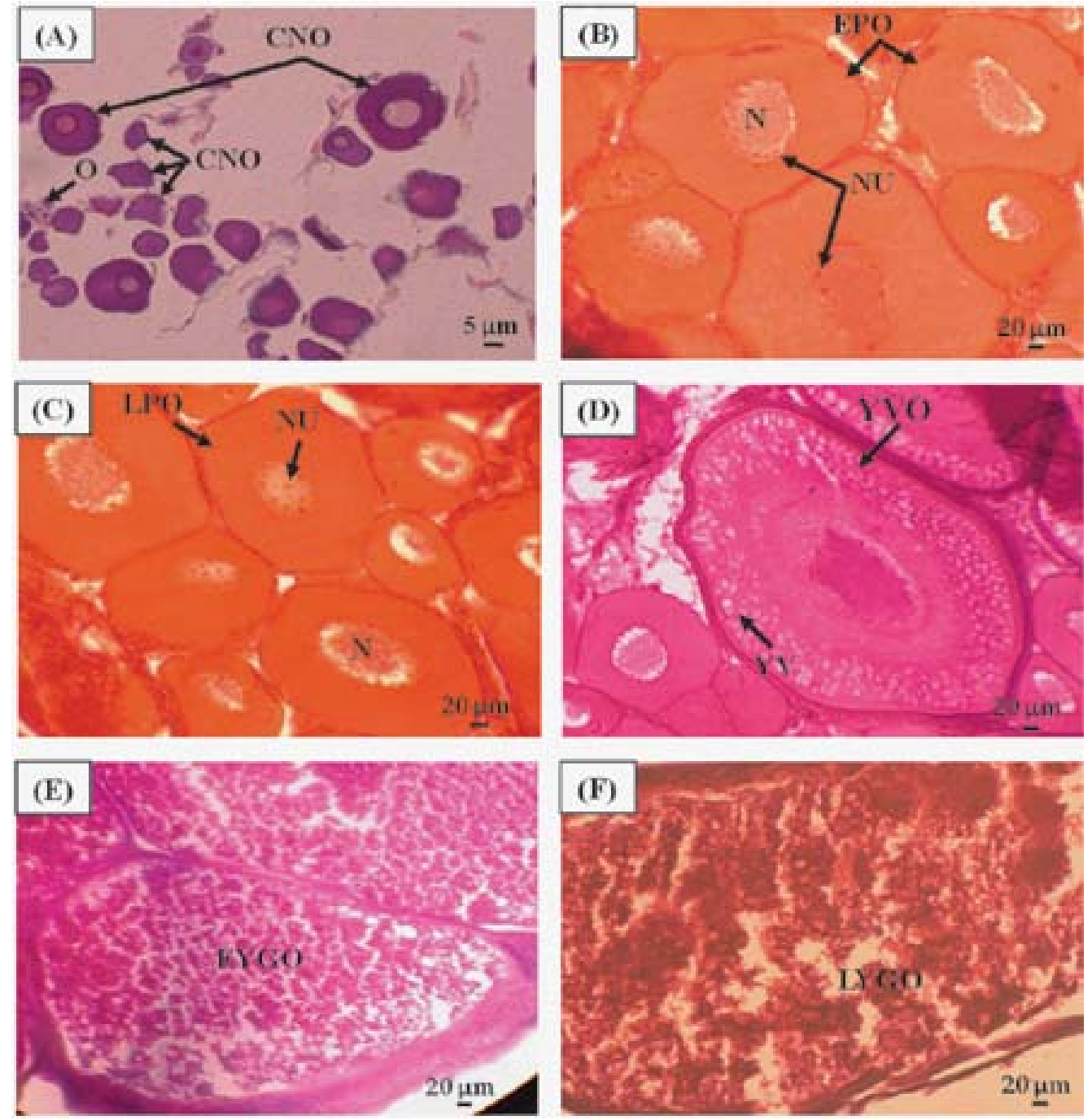

Fig. 2. Transverse sections through ovaries of $M$. armatus illustrating oogenesis: A) oogonia and chromatin nucleolar stage oocytes during the month of October; (B) early perinucleolar stage oocytes during the month of November; (C) late perinucleolar stage oocytes during the month of December; (D) yolk vesicle stage oocyte during the months of January and February; $(E)$ early yolk granule stage oocyte during the months of March and April; $(F)$ late yolk granule stage oocyte during the months of May and June. Abbreviations: $\mathrm{O}=$ oogonia; $\mathrm{CNO}=$ chromatin nucleolar oocyte; $\mathrm{EPO}=$ early perinucleolar oocyte; $\mathrm{LPO}=$ late perinucleolar oocyte; $\mathrm{YV}=$ yolk vesicle oocyte; EYGO= early yolk granule oocyte; LYGO= late yolk granule oocyte $\mathrm{N}=$ nucleus; $\mathrm{NU}=$ nucleolus; $\mathrm{YV}=$ yolk vesicle. All sections were stained with haematoxylin and eosin (H\&E×200) 


\section{The histology of the testes}

Testes were composed of numerous seminiferous lobules surrounded by connective tissue. The lobules were of various sizes and forms and separated from each other by a thin connective tissue stroma. Primary germ cells occurred in the interstitial tissue as well as in the walls of the existing lobules. They were most dominant and formed nests of spermatogonia. A large number of pyknotic nests of degenerating cells were seen. During the breeding season (April to June) the lobules became greatly distended with spermatids and spermatozoa. The testes contained the following stages of germ cells.

\section{Spermatogonia}

This is the primary stage of spermatogenesis, which are largest germ cells in the testis. It was observed spherical in shape. The cell membrane was clearly identical and oval slightly with basophilic nucleus in the centre of the cell. This stage was observed in the months of August and September (Fig. 3A).

\section{Spermatocytes}

Spermatogonia transformed into spermatocytes in the months of October and November, which were spherical in shape containing a nucleus in the centre and these were the primary spermatocytes. The primary spermatocytes produced secondary spermatocytes after the first meiotic division, which were smaller in size than the primary spermatocytes (Fig. 3B).

\section{Spermatids}

The secondary spermatocytes produced the spermatids after the second meiotic division which was also spherical in shape. This stage functioned as male gametes but produced the functional male gametes called spermatozoa in the next development stage. This stage was observed in the months of January to March (Fig. 3C).

\section{Spermatozoa}

This was the last development stage and functional male gamete of spermatogenesis. Spermatids transformed into spermatozoa by the process of spermatogenesis. This stage was developed in the month of March and prominent in April to July (Fig. 3D).
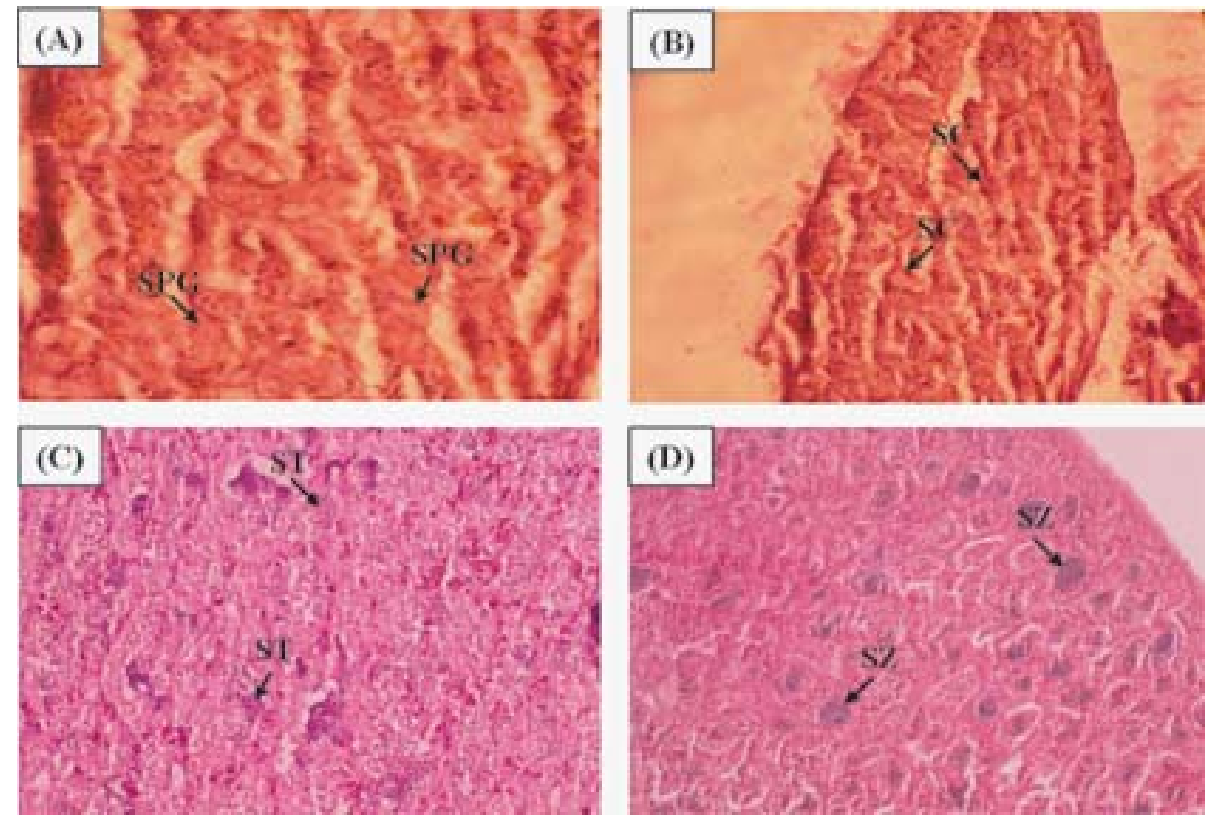

Fig. 3. Transverse sections through testes of $M$. armatus in different maturation stages: (A) spermatogonia dominate in immature testes during August and September; (B) initial maturation stage, spermatocytes were observed during October and November,; (C) testes in advanced maturation when large quantities of spermatids were found in nests surrounding the tubules during December to January to March; (D) testis in mature stage when the tubules were completely filled by spermatozoa during April to July. Abbreviations: $\mathrm{SPG}=$ spermatogonia; $\mathrm{SC}=$ spermatocyte; $\mathrm{ST}=$ spermatids; $\mathrm{SZ}=$ spermatozoa. All sections were stained with haematoxylin and eosin (H\&E×400) 


\section{Discussion}

Histological observation of gonads of $M$. armatus was done to ascertain the actual pattern of gonadal maturation and to find out its breeding season. Ovaries of $M$. armatus were visible to the naked eye as paired, elongated, frilled ribbon organs of various widths lying ventral to the body cavity and were of unequal length, with the right ovary commencing further forwarded than the left ovary, anterior to the gall bladder. The left ovary extended posteriorly beyond the right ovary and terminated posterior to the urogenital opening. The two lobes were connected along the dorsal surface by mesenteris. The colour of ovary varied from reddish brown to light-yellowish. These findings were similar to Rahman (2007), Jahan et al. (2014), and Gupta and Banerjee (2016) who studied the morphology of the ovaries of spiny eel, $M$. armatus and mud eel, M. cuchia. Walsh et al. (2003) was also found almost a similar opinion about the lobes of ovary, their shape, location, commencing and ending position in case of Australian long finned river eel, Anguilla reinhardtii. Colombo et al. (1984) observed the ovaries of European eel, Anguilla anguilla, to the naked eye as frilled ribbon organs of various widths.

It was observed that fish exclusively in immature stages (early and late perinucleolar stage oocytes) of maturity during the months of November and December. Yolk vesicle stage oocytes appeared in the months of January and February. Early yolk granule stage oocytes appeared in the month of March and April while late yolk granule stage oocytes were observed in the months of May to June. These findings agreed with Rahman (2007) who carried out an experiment on cyclic gonadal development of spiny eel, M. armatus and mud eel, M. cuchia. The occurrence of two types of yolk inclusions (yolk vesicles and yolk granules) as observed in $M$. armatus have also been found in many other teleosts (Malone and Hisaoka, 1963; Khoo, 1979). These two types of yolk were found to form sequentially with the yolk vesicles deposited before yolk granules. However, the occurrence of two types is not universal among teleosts (Khoo, 1979). The yolk vesicles in $M$. armatus have been found to follow the same centripetal sequence of development as observable in most of the teleosts such as M. cuchia (Rahman, 2007; Jahan et al., 2014), Tandanus tandanus (Davis, 1977), and Carassius auratus (Khoo, 1979). The yolk granules started to form in $M$. armatus only after the yolk vesicles are fully developed. Yolk vesicles are distinguishable from yolk granules by their smaller size and staining characteristics. Khoo (1979) described that the yolk vesicles of $C$. auratus oocytes stained light blue with Mallory's trichrome while they seemed to be empty when stained with hematoxylin and eosin, which was an artifact.

The male reproductive system of $M$. armatus consisted of a pair of testes that were elongated, situated on either side, ventral to the kidneys in the posterior region of the abdominal cavity and attached to the dorsal body wall by the connective tissue, the mesorchium. Testes were extended unequally along both sides. The colour of testes varied from whitish to creamy white or dull white and were smooth on both sides with distinct lobe. These findings were similar to Rahman (2007), Jahan et al. (2014), and Gupta and Banerjee (2016) who studied the morphology of the testes of $M$. armatus and M. cuchia. Various size and form of numerous seminiferous lobules of testes were separated from each other by a thin connective tissue stroma. Primary germ cells occurred in the interstitial tissue as well as in the walls of the existing lobules. They were most dominant and formed nests of spermatogonia. A large number of pycnotic nests of degenerating cells were seen in the months of August and September. During the breeding season the lobules became greatly distended with spermatids and spermatozoa. The testes contained primary germ cells, spermatogonia, primary and secondary spermatocytes, spermatids and spermatozoa. Rahman et al. (2004), Rahman (2007), and Gupta and Banerjee (2016) were of similar opinion regarding testes location, colour, shape, connecting tissue, separation of lobules from each other for $M$. armatus. In male $M$. armatus, four stages of spermatogenesis were distinguished such as, i) spermatogonia ii) spermatocytes iii) spermatids and iv) spermatozoa which were similar to the findings of Rahman (2007) who worked on cyclic gonadal development of spiny eel, M. armatus. These findings were also similar to the finding of Mollah (1988).

The natural breeding cycle of various eel differs from region to region. European eels, Anguilla anguilla spawn in the late winter months to the early summer months (Horie et al., 2004). On the other hand, New Zealand eels, Anguilla dieffenbachia breed between February and March (Cairns, 1950). Working on M. armatus Rahman (2007) recorded its breeding period in the months of April to July at Mymensingh 
district, Bangladesh. In another study, Farid (2009) found that Macrognathus aculeatus breeds from May to middle of August where the peak breeding season was in June and July. Although not confirmed through histological study but based on the observation of morphology of the gonad, ova diameter, estimation of gonadosomatic index (GSI) and fecundity, both Narejo (2003) and Patwary (2013) suggested that $M$. armatus has only one breeding season during May to July with a peak in July; and April to June with a peak in June, respectively. Similar observations were reported by Nabi and Hossain (1996). Narejo et al. (2003) also suggested that $M$. armatus is synchronous breeder i.e. both the male and female fish came to maturity at the same time in a year.

In the present study, it was observed that the M. armatus breeds from May to June. Most of the reports indicate that although the breeding season for both European and Asian eels may vary as to the month of occurrence, it nearly always coincides with the onset of the rainy season. However, some investigators have suggested that besides rainfall other environmental factors such as temperature (Sundararaj and Vasal, 1976; Spieler et al., 1977) may also influence the onset of spawning. So, ovarian and testicular development study of $M$. armatus indicated that the fish breed during May to June in the natural habitat in Bangladesh.

\section{Acknowledgements}

The authors gratefully acknowledge the PIU-BARC (NATP: Phase-1) for providing financial support to conduct this research work.

\section{References}

Ahmed, A.T.A. 2015. Studies on the fisheries potentials in the hilly areas of Bangladesh. A Final Project Report. Department of Zoology, University of Dhaka (Funded by Ministry of Education, People's Republic of Bangladesh as a grant for advanced research in science). pp. 235.

Alam, M.M., Flowra, F.A., Hussain, M.A. 2013. Diet composition and feeding intensity of wild zigzag eel, Mastacembelus armatus. Trends Fish. Res., 2: 24-26.

Ali, M.R., Mollah, M.F.A., Sarder, M.R.I. 2013. Fecundity and gonado-somatic index of wild freshwater spiny eel Mastacembelus armatus (Lacepede) from Kishoreganj region of Bangladesh. J. Bang. Agril. Uni., 11: 365-372.

Cairns, D. 1950.New Zealand Freshwater Eels. Tuatara, 3: 43-52.

Colombo, G., Grandi, G., Rossi, R. 1984. Gonadal differentiation and body growth in Anguilla anguilla L. J. Fish Biol., 24: $215-228$.

Davis, T.L.O. 1977. Reproductive biology of the freshwater catfish, Tandanus tandanus Mitchell in the Gwydirriver, Australia. I. Structure of the gonads. Aust. J. Mar. Freshw. Res., 28: 139-158.

Farid, S.M. 2009. Induction of spawning, larval rearing and culture of Tarabaim, Macrognathus aculeatus (Bloch). Ph.D Thesis, Department of Fisheries Management, Bangladesh Agricultural University, Mymensingh, $181 \mathrm{pp}$.

Gupta, S., Banerjee, S. 2016. Food, Feeding Habit and Reproductive Biology of Tire-track Spiny Eel (Mastacembelus armatus): A Review. J. Aquac. Res. Dev., 7: 429.

Horie, N., Mikawa, N., Tanaka, S., Oka, H. 2004. Artificial hybrid between A. anguilla and A. japonica. J. Fish Biol., 64 (5): $14-50$.

Humason, G.L. 1972. Animal tissue techniques. WH Freeman and Company, Sanfrancisco, CA, pp. 614.

IUCN, Bangladesh. 2015. Red List of Bangladesh Volume 5: Freshwater Fishes. IUCN, International Union for Conservation of Nature, Bangladesh Country Office, Dhaka, Bangladesh, pp xvi+360

Jahan, D.A., Rashid, J., Khan, M.M., Mahmud, Y. 2014. Reproductive biology and gonad histology of mud eel, Monopterus cuchia (Hamilton, 1822). Int. J. Life Sci. Biotech. Pharma Res., 3(1): 231-239.

Karlou-Riga, C., Economidis, P.S. 1997. Spawning frequency and batch fecundity of horse mackerel, Trachurus trachurus (L.), in the Saronikos Gulf (Greece). J. Appl. Ichthyol. 13:97-104.

Keene, J.I., Noakes, D.L.G., Moccia, R.D., Soto, C.G. 1998. The efficacy of clove oil as an anesthetic for rainbow trout, Oncorhynchus mykiss (Walbaum). Aquacult. Res. 29: 89-101.

Khoo, K.H. 1979. The histochemistry and endocrine control of vitellogenesis in goldfish ovaries. Can. J. Zool., 57: 617-626.

Malone, T.E. Hisaoka, K.K. 1963. A histochemical study of the formation of deutoplasmic components in the developing oocytes of zebrafish, Brachydanio rerio. J. Morphol. 112:61-76.

Mollah, M.F.A. 1988.The annual cycle in the testis of freshwater catfish Clarias macrocephalus (Gunther). In. J. Fish., 35: 99-106.

Mollah, M.F.A., Ali, M.R., Taslima, K. 2013. Domestication and observation on induced breeding of spiny eel Mastacembelus armatus. Am. J. Food Sci. Technol., 1(4): 82-86. 
Nabi, M.A., Hossain, M.A. 1996: Reproductive biology of freshwater spiny eel, Macrognathus aculeatus (Bloch). Bangladesh J. Zool., 24: 115-120.

Narejo, N.T. 2003. Comparative studies on the biology and culture of Monopterus cuchia and Mastacembelus armatus of Mymensingh region. Ph.D. Thesis, Department of Aquaculture, Bangladesh Agricultural University, Mymensingh, Bangladesh, pp. 205..

Patwary, Y.A. 2013. Study on morphometric and meristic measurements and some aspects of reproductive biology of spiny eel, Mastacembelus armatus (Lacepede, 1800). MS Thesis. Department of Fisheries Biology and Genetics. Bangladesh Agricultural University, Mymensingh, Bangladesh.

Rahman, M.M. 2007. Reproductive biology and fry rearing of freshwater eels Monopterus cuchia (Ham.) and Mastacembelus armatus (Lacep.) of Mymensingh, Bangladesh. PhD thesis, Department of Aquaculture, Bangladesh Agricultural University, Mymensingh, Bangladesh, pp. 172.

Rahman, M.M., Ahmed, G.U., Rahmatullah, S.M. 2004. Changes in gonad of wild freshwater spiny eel, Mastacembelus armatus (Lacepede) during early spent period collected from a river of Netrokona district, Bangladesh. Prog. Agric., 15: 115-120.

Rahman, M.M., Ahmed, G.U., Rahmatullah, S.M. 2004. Changes in gonad of wild freshwater spiny eel M. armatus (Lacepede) during early spent period collected from a river of Netrokona district, Bangladesh. Prog. Agric., 15: 115-120.

Rahman, M.M., Ahmed, G.U., Rahmatullah, S.M. 2006. Fecundity of wild freshwater spiny eel Mastacembelus armatus Lacepede from Mymensingh region of Bangladesh. Asian Fish. Sci., 19: 51-59.

Serajuddin, M., Khan, A.A., Mustafa, S. 1998. Food and feeding habits of the spiny eel, Mastacembelus armatus . Asian Fish. Sci., 11: 271-278.

Serajuddin, M., Pathak, B.C. 2012. Study of reproductive traits of spiny eel, Mastacembelus armatus (Mastacembeliforms) from Kalinadi - a tributary of the Ganges river basin, India. Res. J. Biol., 2: 145-150.

Spieler, R.E., Noeske, T.A., De Vlaming, V.L., Meier, A.H. 1977. Effects of thermocycles on body weight gain and gonadal growth in the goldfish, Carassius auratus. Trans. Am. Fish. Soc., 106: 440-444.

Sundararaj, B.I., Vasal, S. 1976. Photoperiod and temperature control in the regulation of reproduction in the female catfish Heteropneustes fossilis. J. Fish. Res. Board Can., 33: 959-973.

Talwar, P.K., Jhingran, A.G. 1991. Inland fishes of India and adjacent countries. Oxford and IBH Publishing Co. Pvt. Ltd. New Delhi, Bombay and Calcutta, India. pp. 514.

Walsh, C.T., Pease, B.C., Booth, D.J. 2003. Sexual dimorphism and gonadal development of the Australian long finned river eel. J. Fish Biol. 63: 137-152.

West, G. 1990. Methods of assessing ovarian development in fishes: a review. Aust. J. Mar. Freshw. Res., 41: $199-222$. 